\title{
Microarray analysis highlights immune response of Pacific oysters as a determinant of resistance to summer mortality
}

\author{
Elodie Fleury ${ }^{1,2}$ and Arnaud Huvet ${ }^{1, *}$ \\ 1 Ifremer, UMR 100 Physiologie et Ecophysiologie des Mollusques Marins, Centre de Brest, BP 70, 29280 \\ Plouzané, France \\ ${ }^{2}$ Present address : Ifremer, LER/MPL, 12 rue des Résistants, 56470 La Trinité Sur Mer, France \\ *: Corresponding author : Arnaud Huvet, email address : ahuvet@ifremer.fr
}

\begin{abstract}
:
Summer mortality of Crassostrea gigas is the result of a complex interaction between oysters, their environment, and pathogens. A high heritability was estimated for resistance to summer mortality, which provided an opportunity to develop lines of oysters that were resistant (R) or susceptible (S) to summer mortality. Previous genome-wide expression profiling study of $R$ and $S$ oyster gonads highlighted reproduction and antioxidant defense as constitutive pathways that operate differentially between these two lines. Here, we show that signaling in innate immunity also operates differentially between these lines, and we hypothesize that this is at the main determinant of their difference in survival in the field. A reanalysis of our published microarray data using separate ANOVAs at each sampling date revealed a specific "immune" profile at the date preceding the mortality. In addition, we conducted additional microarray profiling of two other tissues, gills, and muscle, and both showed an overrepresentation of immune genes (46\%) among those that are differentially expressed between the two lines. Eleven genes were pinpointed to be simultaneously differentially expressed between $R$ and $S$ lines in the three tissues. Among them, ten are related to "Immune Response." For these genes, the kinetics of $R$ mRNA levels between sampling dates appeared different just before the morality peak and suggests that under field conditions, $\mathrm{R}$ oysters had the capacity to modulate signaling in innate immunity whereas $S$ oysters did not. This study enhances our understanding of the complex summer mortality syndrome and provides candidates of interest for further functional and genetics studies.
\end{abstract}

Keywords : Mollusca ; Crassostrea gigas ; Gene ; Immunity ; cDNA microarray ; Summer mortality 


\section{Introduction}

Significant mortality in Pacific oyster Crassostrea gigas has been reported to occur during the summer months in several countries and is a major concern for oyster aquaculture. This phenomenon is multifactorial, resulting from a complex interaction between oysters, their environment and pathogens (Samain and McCombie, 2008). More precisely, summer mortalities of C. gigas spat result from opportunistic pathogens, Ostreid herpes virus type 1 (OsHV-1) (Renault et al., 1994; Sauvage et al., 2009; Schikorski et al., 2011) and different species of bacteria belonging to the genus Vibrio (Garnier et al., 2007; Labreuche et al., 2010, Le Roux et al., 2002), that infect oysters weakened by a combination of abiotic stress (Lang et al., 2009) and the high energetic demands of reproduction (Fleury et al., 2010).

Variation in resistance to summer mortality is highly heritable (Dégremont et al., 2005; 2007), which provided an opportunity to develop lines of oysters that were "resistant" (R) or "susceptible" (S) to summer mortality (Samain and McCombie, 2008). To further investigate the physiological differences between the $\mathrm{R}$ and $\mathrm{S}$ lines and identify molecular markers for resistance to summer mortality, we recently conducted a genome-wide expression profiling study of $R$ and $S$ gonads using a 9X cDNA microarray specific to $C$. gigas (Fleury et al., 2010). The ANOVA used for the previous study used a statistical model with three factors : "line" (R or S), "date of sampling" (May, $9^{\text {th }}$, May, $25^{\text {th }}$, June $6^{\text {th }}$ and June $20^{\text {th }}$ ), and technical replicates (spots deposited in duplicates on the slide). Of the 9058 unigenes analyzed, 34 were appeared systematically differentially expressed between $R$ and $S$ lines during the 3-month period preceding a summer mortality outbreak, (i.e. significant for the factor "line" overall the entire duration of the experiment). Annotation of most of these genes highlights reproduction and antioxidant defense as the main pathways that operate differentially between $R$ and $S$ lines in gonadal tissue during the critical period preceding a summer mortality outbreak. Results also showed that the factor "date of sampling" appeared to play a major influence as $23 \%$ of the studied genes were found to vary significantly according to the date (Fleury et al., 2010), but no interaction was found between "line" and "date of sampling".

In the present paper, we performed a different statistical analysis, a separate ANOVA for each of the dates, for the microarray data obtained on the $R$ and $S$ gonad samples already published in (Fleury et al., 2010). Results revealed a specific profile for the date preceding the mortality outbreak (June $20^{\text {th }}$ ), with more than $54 \%$ of the genes differentially expressed between $\mathrm{R}$ and $\mathrm{S}$ linked to the "immune response" gene ontology (GO) category. In addition, we conducted an expression profiling of two other tissues, gills and muscle, sampled during the same survey and using the same cDNA microarray. Gills and muscle were analyzed because they are the primary tissues involved in responses to biotic or abiotic environmental variations in the context of pathogens or environmental stress associated with summer mortality (Samain and McCombie, 2008). Statistical analysis of the microarray data was performed to test an over-representation of the GO "immune response" for the genes that appeared differentially expressed between $R$ and $S$ in these two tissues prior to the mortality outbreak (June $20^{\text {th }}$ ). The kinetics of gene expression of the immune-relevant genes commonly detected in the three tissues, are then discussed as a potential value in determining resistance to mortality.

\section{Material and methods}

\subsection{Biological material}

Following a divergent selection experiment on spat survival (Dégremont et al., 2007; Samain and McCombie, 2008), a fourth generation of $C$. gigas lines resistant (R) and susceptible (S) to summer mortality was produced in March 2004 at the IFREMER hatchery in La Tremblade (France). Intraline crosses of "G3c2" generation gave the "G4R" and "G4S" batches according to the crossing design described in Fleury et al. (2010). Briefly, five hundred oysters per G4R and G4S batch were kept at the Bouin nursery (France) away from mortality risks. After 12 months (March 
2005), G4R and G4S pools, with a mean weight of 1.26 and $1.38 \mathrm{~g}$ respectively, were deployed in the field at Fort Espagnol (South Brittany, France). They were cultured in triplicate plastic bags fixed on racks at $70 \mathrm{~cm}$ out off the ground as the proximity of sediment have been shown to be a worsening factor in summer mortalities. The density of oysters per bags was 200 , and they were cleaned every month during all the in situ experiment.. Mortality was monitored as described in (Fleury et al., 2010): respectively $56 \%$ and $22 \%$ cumulative mortality had been observed for $S$ and $\mathrm{R}$ lines during the mortality peak (July, $7^{\text {th }}$ ), representing a substantially 2.5 times higher mortality rate in S oysters compared to R oysters. Gonad samples from R and $S$ lines were the same as those previously described in Fleury et al. (2010). Muscle and gills were sampled three times (May $25^{\text {th }}$, June $6^{\text {th }}$, June $20^{\text {th }}$ ). On each analyzed date, 24 oysters per line were randomly collected ( 8 per bag) and their tissues were immediately dissected. For each tissue, samples were then pooled (3 pools of 8 oysters), homogenized in Extract-all (Eurobio) at a concentration of $1 \mathrm{ml} / 50 \mathrm{mg}$ tissue and stored at $-80^{\circ} \mathrm{C}$ for subsequent total RNA extraction. To ensure that each individual will contribute equally to the pool, a piece of $30 \mathrm{mg}$ of each tissue was sampled per oyster separately. Furthermore, the whole bodies of 10 wild oysters were collected in the Marennes Oleron basin (France), pooled and homogenized in Extract-all (Eurobio) to constitute a single total RNA sample for use as a reference in all slide hybridizations.

\subsection{RNA preparation}

Samples of gonad, muscle and gills in Extract-all (Eurobio) were taken frozen and solubilized using a Brinkman Polytron tissue disruptor. Total RNA of each tissue was then isolated using Extract-all (Eurobio) procedure. RNA quality was assessed using RNA nano chips and Agilent RNA 6000 nano reagents (Agilent Technologies, Waldbronn, Germany) according to manufacturer's instructions. RNA concentrations were measured using an ND-1000 spectrophotometer (Nanodrop Technologies) at $260 \mathrm{~nm}$ using the conversion factor $1 \mathrm{OD}=40 \mu \mathrm{g} / \mathrm{ml} \mathrm{RNA}$.

For microarray hybridizations, $5 \mu \mathrm{g}$ of total RNA were directly labeled by reverse transcription and then purified using the Direct ChipShot Labeling kit (Promega), according to manufacturer's recommendations. This reaction was performed for each of the 18 muscle samples and the 18 gills samples with Cy5 (red) incorporation. The reference sample (wild oysters) was Cy3-labeled (green) in 36 separate tubes following the same protocol. The 36 Cy3-labeled cDNAs were next pooled, and then divided once more into 36 samples to obtain a homogeneous reference. All dye incorporation rates were verified by ND-1000 spectrophotometer (Nanodrop Technologies) prior to any hybridization.

\subsection{Microarray hybridizations}

The 9X cDNA microarray slide, containing a total of 11088 features spotted in duplicate (9058 cDNA clones plus controls including water, spotting buffer, and calibration control with a standard fluorescence), and the hybridization procedure were the same as in Fleury et al. (2010). The array design is accessible through Gene Expression Omnibus (GSE16448). Briefly, for each tissue, equimolar amounts of cDNA samples and cDNA reference labeled with Cy5 and Cy3, respectively, were SpeedVac evaporated and mixed into a single pool with the hybridization buffer (ChipHybe ${ }^{\mathrm{TM}}$ hybridization buffer, Ventana Discovery, Tucson, AZ, USA). They were then co-hybridized on the same microarray slide, in a Ventana hybridization station (Ventana Discovery, Tucson, AZ, USA). Hybridizations were performed at the INRA IFR 140 transcriptomic facility (Rennes, France). Slides were filled with a pre-hybridization buffer for 1 hour at $42^{\circ} \mathrm{C}$ in a humidified chamber. Following this pre-hybridization step, hybridization was conducted overnight at $42^{\circ} \mathrm{C}$ in a humidified chamber. The arrays were washed twice at room temperature with Ribowash solution, twice with $0.1 \times S S C$ and finally centrifuged for drying.

After the hybridization step, microarray slides were scanned using a Scanner Genepix 4000B (Axon Instruments Inc.) with standard dual laser excitation at $532 \mathrm{~nm}(17 \mathrm{~mW})$ and $635 \mathrm{~nm}(10$ $\mathrm{mW}$ ) according to the following parameters: Cy 5 Photo Multiplier Tube (PMT): 550 and Cy 3 PMT: 
590. This process was repeated for each of the 36 hybridized slides with the high-resolution mode ( $5 \mu \mathrm{m}$ resolution). The images were then analyzed using Genepix pro 5.1 software (Axon Instruments Inc.) according to manufacturer's instructions. Spots were filtered for quality according to the criteria defined in Fleury et al. (2010) and spots not fulfilling these criteria were removed from the data set.

\subsection{Microarray data analyses}

\subsubsection{Correction and normalization}

Transformation and normalization of hybridization data were performed by Log and standardisation respectively, in order to minimize variation arising from technical differences in RNA quality, probe labelling, and hybridization conditions between experiments. As normalization without background subtraction resulted in the lowest variability, microarray data background has not been corrected prior to data_correction and normalization, as suggested by Zahurak et al. (2007). First, a logarithmic transformation for each signal intensity was performed in all filtered sets to obtain Log (hybridization values). Considering that expression of the majority of the spotted genes did not change with the experimental conditions, the total quantity of cDNA (sum of Log hybridization values) and the variance of Log (hybridization values) within each set should be the same across the different samples. For this reason, a median normalization has been performed by subtracting the median of Log (hybridization values) in a set (sample) from each Log (hybridization values) for that set (to obtain Log normalized hybridization values), as described in Rezen et al. (2008). Correction for differences in the variance across the range of gene expression levels were next performed by dividing each Log (normalized hybridization values) by the standard deviation of the Log (normalized hybridization values) for each set, as described in Darias et al. (2008). The corrected and normalized data are available in Gene Expression Omnibus (GSE25614). Microarray data obtained on gonad samples were already validated by real-time PCR based on a significant correlation $\left(R^{2}=0.89\right)$ of the gene expression assays between the two methods (see Fleury et al., 2010). Furthermore, fold changes between $\mathrm{R}$ and $\mathrm{S}$ samples appeared extremely similar between the two methods, as the highest difference in fold changes obtained between the two methods was $4.2 \%$ attesting the reliability of the present data.

\subsubsection{Identification of differentially expressed genes}

Genes that were differentially expressed between $\mathrm{R}$ and $\mathrm{S}$ lines at each sampling date and for each tissue were determined statistically $\left(p\right.$-value $\left.<10^{-4}\right)$ by variance analysis using GeneANOVA software (Didier et al., 2002). The False Discovery Rate (FDR) associated with the selected genes was thus determined by the formula: [Total number of analyzed genes (9058) $\times p$-value $\left(10^{-4}\right) /$ number of differentially expressed genes] x 100. For each analysis (i.e each date and each tissue), we constructed a statistical model with 2 factors: "line" (R or S) and "technical replicate" (spots deposited in duplicate on the slide). The common selected genes in gonad, muscle and gills at June $20^{\text {th }}$ were kept for pattern expression analysis, to visually inspect if these genes have similar patterns between each sampling dates. .Student t-tests were realized on the transformed normalized Cy5 log value of each gene between dates, for $R$ and $S$ lines respectively, as detailed in Yuan et al. (2006).

\subsubsection{Gene ontology analyses}

Gene ontology analysis was carried out for each list of selected genes (by date and by tissue), using the BLAST2GO program (Conesa et al., 2005). This program is a Java application enabling gene ontology (GO) assignment, based on data mining of sequences for which no $G O$ annotation is currently available. FASTA-formatted sequences representing the selected ESTs were uploaded into the program and BLASTX similarity searches were carried out against the Swiss-Prot 
database (http://blast.ncbi.nlm.nih.gov/Blast.cgi). The program retrieved the $\mathrm{GO}$ terms associated with the hits $\left(E\right.$-value $\left.<10^{-5}\right)$ and queries were annotated based on hit similarity and $G O$ evidence codes. Expression Analysis Systematic Explorer (EASE, Hosack et al., 2003) analysis was performed to test selected list of genes against all genes spotted on the chip to discover enriched biological GO category within gene lists. GO categories that showed EASE scores $\leq 0.05$ were considered significantly over-represented.

\section{Results}

\subsection{Identification of Differentially Expressed Genes}

Analysis of variance (ANOVA) for the gonad tissue revealed respectively 34,55 and 60 differentially expressed genes between $R$ and $S$ lines for the 3 studied dates, May $25^{\text {th }}$, June $6^{\text {th }}$, June $20^{\text {th }}$, respectively. For muscle 20,39, 32 genes and for gills 49,70 and 72 genes were differentially expressed between R and S oysters for the dates May $25^{\text {th }}$, June $6^{\text {th }}$ and June $20^{\text {th }}$, respectively. The level of significance used for all ANOVA analysis to select these ESTs as differentially expressed was $p$-value $<10^{-4}$. Consequently, the FDR values of selected ESTs for each date and for each tissue were always under $5 \%(2.6 \%, 1.6 \%$ and $1.5 \%$ for the gonad, $4.5 \%$, $2.3 \%$ and $2.8 \%$ for the muscle and $1.8 \%, 1.2 \%$ and $1.2 \%$ for the gills for the 3 dates, respectively).

\subsection{Annotation and Gene Ontology analyses of the selected genes}

Compiled BLAST analyses revealed that $84 \%$ of the differentially expressed ESTs showed significant hits with Swiss-Prot databank sequences (E-value threshold $<10^{-5}$ ). Gene ontology analyses of the annotated clones for the 3 dates and the 3 tissues are presented in Figure 2. For the 2 first dates (May $25^{\text {th }}$, June $6^{\text {th }}$ ), all the biological processes (reproduction, lipid metabolic process, response to stress, cell death, catabolic process, antioxydant activity, growth, immune response, energy reserve metabolic process, and NA when no GO was associated) are almost equally represented for the 3 tissues, and no significant EASE-score was obtained for any of them, meaning that there was no over-representation of these GO categories for these 2 dates. For the last date (June $20^{\text {th }}$ ), $54 \%, 48 \%$ and $45 \%$ of the selected genes were associated with the "immune response" biological process for gonad, muscle and gills, respectively. In comparison, the percentage of genes associated with the "immune response" category was $3 \%$ in the whole cDNA microarray. EASE scores obtained for "immune response" among the lists of genes selected at the June $20^{\text {th }}$ were always under 0.05 , meaning that genes linked with "immune response" biological process appear more often in the given lists than expected under random distribution. The list of the 164 differentially expressed ESTs and their annotation is given for the date June $20^{\text {th }}$ in Table 1. Compiling data from the three tissues, they correspond to 130 single ESTs: 41 specifically selected in gonad, 50 in gills and 16 in muscle (Figure 3). Twenty three were commonly identified in at least two tissues for which $86 \%$ fall into the category "immune response". Eleven genes appeared commonly detected in the 3 tissues, muscle, gills and gonad at the date June $20^{\text {th }}$. Among these, 10 genes fall in the category "immune response" and were considered as 10 immune-relevant transcripts for further investigation.

\subsection{Kinetics of mRNA level of the 10 selected immune genes}

Time course expression analyses for these 10 immune-relevant transcripts selected as differentially expressed between $\mathrm{R}$ and $\mathrm{S}$ oyster lines showed the same pattern for each of the 3 analyzed tissues. Whereas no significant variation of mRNA level was observed in $\mathrm{S}$ oysters along the 3 dates, two coordinate patterns of expression were revealed for $\mathrm{R}$ oysters with significant variations observed at June $20^{\text {th }}$ in comparison with June $6^{\text {th }}$ and May $25^{\text {th }}$ (Figure 4). First cluster 
of co-regulated genes identified the ESTs showing a mean of 3.5x decrease in R mRNA level at the date June $20^{\text {th }}$ for the three tissues in comparison with the 2 previous dates. This cluster grouped ESTs encoding two inhibitors of NF-KB and a suppressor of cytokine signalling. The second cluster corresponded to transcripts over-expressed of around $14 \mathrm{x}$ in $\mathrm{R}$ at the date June $20^{\text {th }}$ compared to the 2 previous dates. This group identified ESTs encoding Toll-like receptor, Bcell lymphoma/leukemia, peroxinectin, complement C1q-like protein, prostaglandin E2 receptor, and two superoxide dismutases.

\section{Discussion}

In this study, we conducted a genome-wide expression profiling of Crassostrea gigas lines selected to be resistant $(R)$ and susceptible $(S)$ to summer mortality to identify specific genes that contribute to resistance to summer mortality, and therefore obtain further insights into the understanding of the complex summer mortality syndrome. We used a cDNA microarray containing 9,085 unigenes from $C$. gigas and to obtain genome-wide expression profiles of muscle and gills samples from $\mathrm{R}$ and $\mathrm{S}$ lines preceding a summer mortality outbreak. We combined these new data with those previously obtained for the gonad from the same individuals and using the same microarray (Fleury et al., 2010). We originally chose to study gonad based on the negative correlation between reproductive effort and resistance to summer mortality, which suggests that summer mortality could be partly due to a physiological disorder and metabolic disturbance in oysters associated with high reproductive effort (Fleury et al., 2010; Huvet et al., 2010; Samain and McCombie, 2008). Moreover, environmental stress and pathogens are known to interact and lead to summer mortality outbreaks. We added gills in this study because they are bathed by hemocytes (Gonzalez et al., 2007; Seo et al., 2005), which play a key role in the immune defense against pathogens (Bachère et al., 2004; Le Foll et al., 2010; Venier et al., 2011). Gills are also known to be involved in stress response in oysters, such as accumulation and detoxification of heavy metals (Macey et al., 2010). As well, the muscle is of importance in bivalves as one of the primary tissue implicated in the adaptation mechanisms to environmental variations such as hypoxic stress (Le Moullac et al., 2007).

The previously genome-wide expression profiling of $\mathrm{R}$ and $\mathrm{S}$ oyster gonads during the 3-month period preceding a summer mortality event highlighted reproduction allocation and antioxidant defense as constitutive pathways that operate differentially between R and S lines (Fleury et al., 2010). Here we showed that signalling in innate immunity operates differentially between these two lines and we hypothesized that this is at the main determinant of their difference in survival in the field. Our analysis of the microarray data from gonad, muscle and gills revealed a specific "immune" profile at the date June $20^{\text {th }}$ corresponding to the date preceding the mortality outbreak.. This significant over-representation of differentially expressed genes associated with "immune response" biological process is in contrast with the biological processes equally represented for the genes differentially expressed at the two previous dates and for the cDNA spotted on the microarray.

From the 60,32 , and 72 ESTs selected at the June $20^{\text {th }}$ for gonad, muscle, and gills, respectively, $44 \%$ appeared over-expressed and $56 \%$ under-expressed in $\mathrm{R}$ lines compared to $\mathrm{S}$ lines overall the three tissues. This suggests that the difference between the two lines is not only due to a physiological weakness of $S$ oysters causing generalized down-regulation of gene transcription. When focusing on immune selected genes, no statistical differences were observed between $\mathrm{R}$ and $S$ lines at May $25^{\text {th }}$ and June $6^{\text {th }}$. Consequently, the kinetics of immune-relevant gene expression, inferred from the microarray data along the temporal sampling, appeared punctually different between the two lines at June $20^{\text {th }}$.. For the 10 immune-relevant genes, pinpointed by the Venn diagram to be simultaneously differentially expressed between $\mathrm{R}$ and $\mathrm{S}$ lines in the three tissues at this date, no significant variation of gene expression was observed in $S$ lines along the three sampling dates whereas significant and strong variations of mRNA level were observed for the $\mathrm{R}$ lines. Indeed, two patterns of coordinately regulated immune-relevant genes were identified in $\mathrm{R}$ lines, 7 transcripts were over-expressed from June $6^{\text {th }}$ to June $20^{\text {th }}$ and 3 transcripts were 
under-expressed from June $6^{\text {th }}$ to June $20^{\text {th }}$. Interestingly, the sense of mRNA level variation of the selected ESTs observed in R oysters is in agreement with their stimulator / inhibitor role known in some vertebrates. ESTs encoding two inhibitors of NF-KB and a suppressor of cytokine signalling appeared to be down-regulated at the June $20^{\text {th }}$ whereas the other ESTs encoding genes implicated in the detection of pathogens, the activation of signal transduction and of appropriate defenses appeared to be strongly up-regulated. In our field experiment, R oysters displayed capacity to react, in terms of immune gene expression, whereas the $S$ oysters had not or reacted less, and this might be linked to their ability to survive.

Based on the function of these 10 genes, signalling in innate immunity appears to have a key role in resistance to the summer mortality syndrome. Innate immunity consists of three steps: detection of pathogens, activation of signal transduction, and mounting of appropriate defenses (Foley and O'Farrell, 2004). Pathogen signature, such as microbial components, are detected by host recognition receptors including Toll-like receptors (TLRs) responsible for the activation of NF\& \& pathway and phagocytosis. One differentially expressed transcript encodes a TLR which is different from the already characterized TLR4 in C. virginica (Tanguy et al., 2004) or Cg-Toll-1 in C. gigas (Zhang et al., 2011) and might correspond to a TLR-type 3 known in vertebrates to recognize microbial nucleic acids and to induce antiviral immune response (Kawai and Akira, 2010). Indeed, TLR3 triggers antiviral immune responses through the production of inflammatory cytokines via the NF-KB pathway, which suggests that TLR3 has an essential role in preventing virus infection. Indeed, studies realized in humans showed the association betweenTLR3 deficiency and susceptibility to herpes simplex virus type 1 (Kawai and Akira, 2010). The involvement of B-cell lymphoma/leukemia (BCL)-10, one of the 10 candidate ESTs, in the activation of NF-kB, by both canonical and non-canonical pathways, has been very well documented. B-cell lymphoma protein is a transcriptional repressor which once phosphorylated, is degraded by ubiquitin/proteasome pathway. A TLR-BCL10 pathway and a reactive oxygen species-Heat shock protein27 pathway were demonstrated to activate NF-KB in human in response to LPS (Bhattacharyya et al., 2010).

Two types of IKBs (Inhibitor of $\mathrm{KB}$ ) were characterized to be differentially expressed between R and $S$ lines and might play a pivotal role in regulating the innate immune response of $C$. gigas. One is $58 \%$ identical with the amino acid sequence of a IKB recently identified in the pearl oyster Pinctada fucata (Zhang et al., 2009). The second EST displayed the highest identity with an inhibitor $\mathrm{kB}$ characterized in Argopecten irradians (Mu et al., 2010). The 50 and 36\% of amino acid identity obtained, respectively, with the inhibitor of NF-KB already characterized in $\mathrm{C}$. gigas and named $\mathrm{Cg}$ IKB (Montagnani et al., 2008) is quite low, suggesting newly-characterized inhibitors of NF-kB in $C$. gigas. The conserved lysine and serine residues required for inducible degradation of the IKB proteins are present in the two sequences and full length cDNA should be further characterized to look for ankyrin repeats, a common feature of most IKBs necessary for specific binding to NF-kB. During inflammatory responses, the phosphorylation of inhibitors of NF-kB leads to the dissociation of the inhibitor/ NF-KB complex and ultimately the degradation of inhibitors. The NF-KB protein complex is subsequently free to translocate to the nucleus where it stimulates the transcription to activate target genes that have DNA-binding sites for NF-KB, notably those involved in immune responses.

Cytokines are potent activators of NF-KB. Therefore, the suppressor of cytokine signalling, identified among the 10 immune-relevant genes, is expected to limit NFKB signalling following a classical negative feedback system that regulates cytokine signal transduction (Alexander and Hilton, 2000). The strong decrease of its mRNA level observed in our data suggests the engagement in $\mathrm{R}$ oysters of cytokines that trigged the inflammatory response.

Pathogens induce phagocytosis and elicit a large amount of reactive oxygen species (ROS) in the host, which had stimulatory effects on NF-kB signalling. ROS, together with lysosomal cytotoxic components, kill pathogens but also produce oxidative damage to biological macromolecules such as DNA, RNA, protein and lipids (Cutler, 1991; Feuers et al., 1993). A greater capacity to rapidly detoxify the ROS contributes to cellular host protection by preventing host cellular oxidative damage and may therefore improve oyster survival. This is the function of SOD, an enzyme upregulated after hypoxic stress in oysters (Sussarellu et al., 2010), that converts $\mathrm{O}_{2}^{-}$into the less 
damaging $\mathrm{H}_{2} \mathrm{O}_{2}$. Two SOD sequences were already characterized to be differentially expressed between $R$ and $S$ lines during the critical period (Fleury et al., 2010; Huvet et al., 2004). The first one was identified as a plasma extracellular Cu/Zn SOD ( $\mathrm{Cg}$-EcSOD) (Gonzalez et al., 2005) and the second as a manganese-SOD (Genbank accession ABZ90958). Here, two ESTs differentially expressed before the mortality outbreak, displayed significant hits with another Cu/Zn SOD already characterized in C. gigas (Boutet et al., 2004). These findings suggest that the capacity of antioxidant enzymes to detoxify the ROS could be critical in determining susceptibility or resistance to summer mortality, as already hypothesized by Lambert et al. (2007). Activity of antioxidant enzymes was already reported for the mollusk Biomphalaria glabrata to be positively correlated with resistance to the parasite Schistosoma mansoni (Goodall et al., 2004). In C. virginica, challenge with Perkinsus marinus caused the up-regulation of a large set of genes likely involved in the regulation of oxidative stress emphasizing the antioxidant defense system as a main pathway for protection against pathogens and diseases (Wang et al., 2010).

Other immune candidates are clearly of interest based on their previous identification in lowsurviving oyster families produced in west coast of USA (Lang et al., 2009; Taris et al., 2009). For example, peroxinectin is a cell-adhesion protein with peroxidase activity and is synthesized and stored in hemocytes. When released, peroxinectin mediates hemocyte adhesion to foreign particles and stimulates phagocytosis (Liu et al., 2007). A prostaglandin receptor and C1q domaincontaining gene were reported to be constitutively higher in low-surviving oyster families as it is the case in our $S$ oyster lines for ESTs annotated as a Complement C1q-like protein and a Prostaglandin E2 receptor. Prostaglandins are oxygenated compounds derived from polyunsaturated fatty acids that play various physiological roles when linked to their receptors including mounting immune and inflammatory responses (Taris et al., 2009). In C. gigas, the EP4 subtype of prostaglandin E2 receptor appeared very strongly up-regulated in gills following bacterial challenge allowing the authors to conclude that this EST is very interesting for further understanding of inflammation in oysters (Roberts et al., 2009). The C1q domain-containing proteins include a wide range of signalling molecules and are known to participate in the control of inflammation, innate immunity and energy homeostasis (Gerdol et al., 2011; Taris et al., 2009).

Lastly, another immune relevant-candidate is annotated as Defensin, , a recently characterized antimicrobial peptide in oyster, which is an important component of the innate immune system and constitutes a first line of defense against pathogen colonization (Gueguen et al., 2006). Defensin was mainly expressed in mantle edge in oysters (Gueguen et al., 2006) whereas other immunerelevant genes characterized here were expected to have hemocyte-specific expression (for example Cg-EcSOD) (Gonzalez et al., 2005). The common identification of immune-relevant genes in gonad, gills and muscle of $\mathrm{R}$ and $\mathrm{S}$ lines, suggest they were expressed by tissue-bathing hemocytes. Immune genes were already reported in marine bivalves to be highly expressed in gills (He et al., 2011; Zhang et al., 2011). For some of them, more precise investigation revealed their mRNA expression in tissue-infiltrating hemocytes (Gonzalez et al., 2005) at possibly higher levels than in circulating hemocytes (Itoh et al., 2011). Gills were characterized as one organ target for the viral replication of the Ostreid herpes virus 1 implicated in some summer mortality outbreaks (e.g. Schikorski et al., 2011) and thus might be recommended for investigation in challenges employed with the aim of mimicking experimentally summer mortality outbreak.

\section{Conclusion}

Where most of the immune questions were addressed experimentally in marine bivalves, the originality of the present work was addressing the complex summer mortality syndrome in the field where it occurs and where the $\mathrm{R}$ and $\mathrm{S}$ lines were selected. Our data emphasize immune response of oysters in playing a pivotal role in determining susceptibility or resistance to summer mortality, and especially for molecules regulating the NF-KB signalling pathway. The most significant outcome of this study is the identification of transcripts which enhances our understanding of the process that contribute to the differential survival between $\mathrm{R}$ and $\mathrm{S}$ lines in the context of a summer mortality outbreak. Genes linked to immune response provide basic insights into oyster biology and 
candidates genes for further study, with the aim of enabling marker-aided selection to improve C. gigas oyster survival. More specific and precise individual investigation of these candidate genes is now required in response to bacterial and viral infections, as well as unravelling their role using functional studies such as RNA interference, now available in oyster (Fabioux et al., 2009).

\section{Acknowledgments}

This study was conducted as part of the European program "Aquafirst" and the network of excellence "Marine Genomic Europe". The authors are grateful to P. Boudry for his support during the course of this work and as the supervisors with L. Dégremont of the selective breeding program. We also acknowledge P. Favrel for helpful discussion. The authors are indebted to J.Y. Daniel, V. Quillien, V. Boulo, C. Sauvage and J. Moal (best wishes for a long and enjoyable retirement) for their helpful assistance. We thank all the staff of the Argenton, Bouin and La Tremblade stations for providing experimental oysters. We are indebted to Scott Pavey for his help in editing the English language. We also thank P. Prunet from INRA-SCRIBE, the SIGENAE team (INRA Toulouse, France) for bioinformatic tool development (http://www.sigenae.org) and the team of the INRA IFR 140 transcriptomic facility (Rennes, France).

\section{References}

Alexander, W.S., Hilton, D.J. (2000). The role of suppressors of cytokine signalling (SOCS) proteins in regulation of the immune response. Ann Rev Immunol 22:503-29.

Bachère, E., Gueguen, Y., Gonzalez, M., de Lorgeril, J., Garnier, J., Romestand, B. (2004). Insights into the anti-microbial defense of marine invertebrates: the penaeid shrimps and the oyster Crassostrea gigas. Immunol Rev 198:149-68.

Bhattacharyya, S., Borthakur, A., Dudeja, P.K., Tobacman, J.K. (2010). Lipopolysaccharideinduced activation of NF-KB non-canonical pathway requires BCL10 serine 138 and NIK phosphorylations. Exp Cell Res 316:3317-27.

Boutet, I., Tanguy, A., Moraga, D. (2004). Response of the Pacific oyster Crassostrea gigas to hydrocarbon contamination under experimental conditions. Gene 329:147-57.

Conesa, A., Gotz, S., Garcia-Gomez, J.M., Terol, J., Talon, M., Robles, M. (2005). Blast2GO: a universal tool for annotation, visualization and analysis in functional genomics research. Bioinformatics 21:3674-6.

Cutler, R.G. (1991). Human longevity and aging: Possible role of reactive oxygen species. Ann NY Acad Sci 621:1-28.

Darias, M.J., Zambonino-Infante, J.L., Hugot, K., Cahu, C., Mazurais, D. (2008) Gene expression patterns during the larval development of European sea bass (Dicentrarchus labrax) by microarray analysis. Mar Biotechnol 10:416-28.

Dégremont, L., Bedier, E., Soletchnik, P., Ropert, M., Huvet, A., Moal, J., Samain, J., Boudry, P (2005). Relative importance of family, site, and field placement timing on survival, growth, and yield of hatchery-produced Pacific oyster spat (Crassostrea gigas). Aquaculture 249:213-29.

Dégremont, L., Ernande, B., Bédier, E., Boudry, P. (2007). Summer mortality of hatchery-produced Pacific oyster spat (Crassostrea gigas). I. Estimation of genetic parameters for survival and growth. Aquaculture 262:41-53.

Didier, G., Brezellec, P., Remy, E., Henaut, A. (2002). GeneANOVA--gene expression analysis of variance. Bioinformatics 18:490-1.

Fabioux, C., Corporeau, C., Quillien, V., Favrel, P., Huvet, A. (2009). In vivo RNA interference in oyster: vasa silencing inhibits germ cell development. FEBS J 276:2566-73.

Feuers, R.J., Weindrch, R., Hart, R.W. (1993). Caloric restriction, aging and antioxidant enzymes. Mutat Res 295:191-200. 
Fleury, E., Huvet, A., Lelong, C., de Lorgeril, J., Boulo, V., Gueguen, Y., Bachère, E., Tanguy, A., Moraga, D., Fabioux, C., Lindeque, P., Shaw, J., Reinhardt, R., Prunet, P., Davey, G., Lapegue, S., Sauvage, C., Corporeau, C., Moal, J., Gavory, F., Wincker, P., Moreews, F., Klopp, C., Mathieu, M., Boudry, P., Favrel, P. (2009). Generation and analysis of a 29,745 unique Expressed Sequence Tags from the Pacific oyster (Crassostrea gigas) assembled into a publicly accessible database: the GigasDatabase. BMC Genomics 10:341.

Fleury, E., Moal, J., Boulo, V., Daniel, J.Y., Mazurais, D., Hénaut, A., Corporeau, C., Boudry, P., Favrel, P., Huvet, A. (2010). Microarray-based identification of gonad transcripts differentially expressed between lines of Pacific oyster selected to be resistant or susceptible to summer mortality. Mar Biotechnol 12:326-39.

Foley, E., O'Farrell, P.H. (2004). Functional dissection of an innate immune response by a genome-wide RNAi screen. PLoS Biol 2:1091-1106.

Garnier, M., Labreuche, Y., Garcia, C., Robert, M., Nicolas, J.L. (2007). Evidence for the involvement of pathogenic bacteria in summer mortalities of the Pacific oyster Crassostrea gigas. Microb Ecol 53:187-96.

Gerdol, M., Manfrin, C., De Moro, G., Figueras, A., Novoa, B., Venier, P., Pallavicini, A. (2011). The $\mathrm{C} 1 \mathrm{q}$ domain containing proteins of the Mediterranean mussel Mytilus galloprovincialis: $A$ widespread and diverse family of immune-related molecules. Dev Comp Immunol 35:635-43.

Gonzalez, M., Gueguen, Y., Desserre, G., de Lorgeril, J., Romestand, B., Bachère, E. (2007). Molecular characterization of two isoforms of defensin from hemocytes of the oyster Crassostrea gigas. Dev Comp Immunol 31:332-9.

Gonzalez, M., Romestand, B., Fievet, J., Huvet, A., Lebart, M.C., Gueguen, Y., Bachère, E. (2005). Evidence in oyster of a plasma Extracellular Superoxide Dismutase which binds LPS. Biochem Biophys Res Commun 338:1089-97.

Goodall, C.P., Bender, R.C., Broderick, E.J., Bayne, C.J. (2004). Constitutive differences in Cu/Zn superoxide dismutase mRNA levels and activity in hemocytes of Biomphalaria glabrata (Mollusca) that are either susceptible or resistant to Schistosoma mansoni (Trematoda). Mol Biochem Parasitol 137:321-8.

Gueguen, Y., Herpin, A., Aumelas, A., Garnier, J., Fievet, J., Escoubas, J.M., Bulet, P., Gonzalez, M., Lelong, C., Favrel, P., Bachère, E. (2006). Characterization of a defensin from the oyster Crassostrea gigas. Recombinant production, folding, solution structure, antimicrobial activities and gene expression. J Biol Chem 281:313-23.

He, X., Zhang, Y., Yu, Z. (2011). An Mpeg (macrophage expressed gene) from the Pacific oyster Crassostrea gigas: Molecular characterization and gene expression. Fish Shellfish Immunol 30:870-6.

Hosack, D.A., Dennis, G. Jr, Sherman, B.T., Lane, H.C., Lempicki, R.A. (2003). Identifying biological themes within lists of genes with EASE. Genome Biol 4:70.

Huvet, A., Herpin, A., Dégremont, L., Labreuche, Y., Samain, J.F., Cunningham, C. (2004). The identification of genes from the oyster Crassostrea gigas that are differentially expressed in progeny exhibiting opposed susceptibility to summer mortality. Gene 343:211-20.

Huvet, A., Normand, J., Fleury, E., Quillien, V., Fabioux, C., Boudry, P. (2010). Reproductive effort of Pacific oysters: a trait associated with susceptibility to summer mortality. Aquaculture 304:95-99.

Itoh, N., Xue, Q.G., Schey, K.L., Li, Y., Cooper, R.K., La Peyre, J.F. (2011). Characterization of the major plasma protein of the eastern oyster, Crassostrea virginica, and a proposed role in host defense. Comp Biochem Physiol 58:9-22.

Kawai, T., Akira, S. (2010). The role of pattern-recognition receptors in innate immunity: update on Toll-like receptors. Nat Immunol 11:373-84.

Labreuche, Y., Le Roux, F., Henry, J., Zatylny, C., Huvet, A., Lambert, P., Soudant, P., Mazel, D., Nicolas, J.L. (2010). Vibrio aestuarianus zinc metalloprotease causes lethality in the Pacific oyster Crassostrea gigas and impairs the host cellular immune defences. Fish Shell Immunol 29:753-8.

Lambert, C., Soudant, P., Delaporte, M., Moal, J., Boudry, P., Jean, F., Huvet, A., Samain, J.F. (2007). Hemocyte characteristics in families of oysters, Crassostrea gigas, selected for differential survival during summer and reared in three sites. Aquaculture 270:276-88. 
Lang, R.P., Bayne, C.J., Camara, M.D., Cunningham, C., Jenny, M.J., Langdon, C.J. (2009). Transcriptome profiling of selectively bred Pacific oyster Crassostrea gigas families that differ in tolerance of heat shock. Mar Biotechnol 11:650-68.

Le Foll, F., Rioulta, D., Boussab, S., Pasquiera, J., Dagherc, Z., Leboulenger, F. (2010). Characterisation of Mytilus edulis hemocyte subpopulations by single cell time-lapse motility imaging. Fish Shellfish Immunol 28:372-86.

Le Moullac, G., Bacca, H., Huvet, A., Moal, J., Pouvreau, S., Van Wormhoudt, A. (2007). Transcriptional regulation of pyruvate kinase and phosphoenolpyruvate carboxykinase in the adductor muscle of the oyster Crassostrea gigas during prolonged hypoxia. J Exp Zool 307A:371-82.

Le Roux, F., Gay, M., Lambert, C., Waechter, M., Poubalanne, S., Chollet, B., Nicolas, J.L., Berthe F. (2002). Comparative analysis of Vibrio splendidus-related strains isolated during Crassostrea gigas mortality events. Aquat Living Resour 15:251-8.

Liu, C.H., Yeh, S.P., Hsu, P.Y., Cheng, W. (2007). Peroxinectin gene transcription of the giant freshwater prawn Machobranchium rosenbergii under intrinsic, immunostimulant, and chemotherapeutant influences. Fish Shell Immunol 22:408-17.

Macey, B.M., Matthew, J., Williams, H.R., Thibodeaux, L.K., Beal, M., Almeida, J.S., Cunningham, C., Mancia, A., Warr, G.W., Burge, E.J., Holland, A.F., Gross, P.S., Hikima, S., Burnett, K.G., Burnett, L., Chapman, R.W. (2010). Modeling interactions of acid-base balance and respiratory status in the toxicity of metal mixtures in the American oyster Crassostrea virginica. Comp Biochem Physiol 155A:341-9.

Montagnani, C., Labreuche, Y., Escoubas, J.M. (2008). Cg-lkappaB, a new member of the IkappaB protein family characterized in the pacific oyster Crassostrea gigas. Dev Comp Immunol 32:182-90.

Mu, C., Yu, Y., Zhao, J., Wang, L., Song, X., Zhang, H., Qiu, L., Song, L. (2010). An inhibitor kappaB homologue from bay scallop Argopecten irradians. Fish Shellfish Immunol 28:687-94.

Renault, T., Le Deuff, R.M., Cochennec, N., Maffart, P. (1994). Herpesviruses associated with mortalities among Pacific oyster, Crassostrea gigas, in France - Comparative study. Revue Méd Vét 145:735-42.

Rezen, T., Juvan, P., Fon Tacer, K., Kuzman, D., Roth, A., Pompon, D., Aggerbeck, L.P., Meyer, U.A., Rozman, D. (2008). The Sterolgene v0 cDNA microarray: a systemic approach to studies of cholesterol homeostasis and drug metabolism. BMC Genomics 9:76.

Roberts, S., Goetz, G., White, S., Goetz, F. (2009). Analysis of genes isolated from plated hemocytes of the Pacific oyster, Crassostrea gigas. Mar Biotechnol 11:24-44.

Samain, J.F., McCombie, H. (2008). Summer Mortality of Pacific Oyster Crassostrea gigas. Ed. Ifremer/Quae, Versailles, France.

Sauvage, C., Pépin, J.F., Lapègue, S., Boudry, P., Renault, T. (2009). Ostreid herpes virus 1 infection in families of the Pacific oyster, Crassostrea gigas, during a summer mortality outbreak: differences in viral DNA detection and quantification using real-time PCR. Virus Res 142:181-7.

Schikorski, D., Faury, N., Pepin, J.F., Saulnier, D., Tourbiez, D., Renault, T. (2011). Experimental ostreid herpesvirus 1 infection of the Pacific oyster Crassostrea gigas: kinetics of virus DNA detection by q-PCR in seawater and in oyster samples. Virus Res 155:28-34.

Seo, J.K, Crawford, J.M., Stone, K.L., Noga, E.J. (2005). Purification of a novel arthropod defensin from the American oyster, Crassostrea virginica. Biochem Biophys Res Commun 338:19982004.

Sussarellu, R., Fabioux, C., Le Moullac, G., Fleury, E., Moraga, D. (2010). Transcriptomic response of the Pacific oyster Crassostrea gigas to hypoxia. Mar Genomics 3:133-43.

Tanguy, A., Guo, X., Ford, S.E. (2004). Discovery of genes expressed in response to Perkinsus marinus challenge in Eastern (Crassostrea virginica) and Pacific (C. gigas) oysters. Gene 338:121-31.

Taris, N., Lang, R.P., Reno, P.W., Camara, M.D. (2009). Transcriptome response of the Pacific oyster (Crassostrea gigas) to infection with Vibrio tubiashii using cDNA AFLP differential display. Anim Genet 40:663-77.

Venier, P., Varotto, L., Rosani, U., Millino, C., Celegato, B., Bernante, F., Lanfranchi, G., Novoa, B., Roch, P., Figueras, A., Pallavicini, A. (2011). Insights into the innate immunity of the Mediterranean mussel Mytilus galloprovincialis. BMC Genomics 12:69. 
Wang, S., Peatman, E., Liu, H., Bushek, D., Ford, S., Kucuktas, H., Quilang, J., Li, P., Wallace, R., Wang, Y., Guo, X., Liu, Z. (2010). Microarray analysis of gene expression in eastern oyster (Crassostrea virginica) reveals a novel combination of antimicrobial and oxidative stress host responses after dermo (Perkinsus marinus) challenge. Fish Shellfish Immunol 29:921-9.

Yuan, J.S., Reed, A., Chen, F., Stewart, C.N. (2006). Statistical analysis of real-time PCR data. BMC Bioinformatics 7:85.

Zahurak, M., Parmigiani, G., Yu, W., Scharpf, R.B., Berman, D., Schaeffer, E., Shabbeer, S., Cope, L. (2007). Pre-processing Agilent microarray data. BMC Bioinformatics 8:142.

Zhang, Y., He, X., Li, X., Fu, D., Chen, J., Yu, Z. (2011). The second bactericidal permeability increasing protein (BPI) and its revelation of the gene duplication in the Pacific oyster, Crassostrea gigas. Fish Shellfish Immunol 30:954-63.

Zhang, D., Jiang, S., Quu, L., Su, T., Wu, K., Li, Y., Zhu, C., Xu, X. (2009). Molecular characterization and expression analysis of the IkappaB gene from pearl oyster Pinctada fucata. Fish Shellfish Immunol 26:84-90.

Zhang, L., Li, L., Zhang, G. (2011). A Crassostrea gigas Toll-like receptor and comparative analysis of TLR pathway in invertebrates. Fish Shellfish Immunol 30:653-60. 
Table 1 List of the differentially expressed ESTs in gonad, muscle, and gills between resistant and susceptible oyster lines at the date Jun

\begin{tabular}{|c|c|c|c|c|c|c|}
\hline Tissue & Genbank accession & Sigenae name & Swiss-Prot hit description & $E$ value & $\begin{array}{l}p \text { Value } \\
\text { ANOVA }\end{array}$ & $\begin{array}{l}\text { Fold } c \\
R / S\end{array}$ \\
\hline \multirow[t]{48}{*}{ Gonad } & AM853409 & cdn19p0001i24 & Complement regulatory protein & $8.00 \mathrm{E}-06$ & $1.40 \mathrm{E}-05$ & 0,19 \\
\hline & AM853211 & cdn19p0001a09 & Calcitonin receptor & $3.00 \mathrm{E}-29$ & $1.10 \mathrm{E}-05$ & 0,24 \\
\hline & CU 686145 & oypm1 0b03f16r1 & Suppressor of cytokine signaling 5 & $3.00 \mathrm{E}-12$ & $2.73 \mathrm{E}-04$ & 0,26 \\
\hline & FP091130 & oyio10b01k20r1 & S-crystallin & $3.00 \mathrm{E}-13$ & 2.86E-04 & 0,30 \\
\hline & CU682837 & oygd $10 \mathrm{~b} 09 \mathrm{c} 10 \mathrm{r} 1$ & NA & & $1.99 \mathrm{E}-04$ & 0,34 \\
\hline & AM856743 & $\operatorname{cdn} 21 \mathrm{p} 0002 \mathrm{p} 18$ & NF-kappa-B inhibitor cactus & $6.00 \mathrm{E}-07$ & $7.60 \mathrm{E}-05$ & 0,35 \\
\hline & AM854660 & cdn20p0001d03 & Kinesin-related protein & $5.00 \mathrm{E}-06$ & $4.00 \mathrm{E}-05$ & 0,39 \\
\hline & AM856987 & $\operatorname{cdn} 21 \mathrm{p} 0003 \mathrm{k} 18$ & NA & & $9.40 \mathrm{E}-05$ & 0,42 \\
\hline & AM853504 & cdn19p0001n04 & NF-kappa-B in hibitor cactus & $4.00 \mathrm{E}-33$ & $2.20 \mathrm{E}-05$ & 0,44 \\
\hline & AM858687 & $\operatorname{cdn} 37 \mathrm{p} 0004 \mathrm{o} 20$ & DNA-dependent protein kinase catalytic subunit & $7.00 \mathrm{E}-38$ & $1.24 \mathrm{E}-04$ & 0,45 \\
\hline & AM859022 & $\operatorname{cdn} 37 \mathrm{p} 0005 \mathrm{n} 23$ & Mitogen-activated protein kinase & $2.00 \mathrm{E}-28$ & $1.28 \mathrm{E}-04$ & 0,47 \\
\hline & CU683455 & oyge09b12j11r1 & NA & & $2.25 \mathrm{E}-04$ & 0,50 \\
\hline & CU685152 & oypg10b07j13r1 & Kinase D-interacting substrate & $7.00 \mathrm{E}-04$ & $2.57 \mathrm{E}-04$ & 0,54 \\
\hline & AM853699 & cdn19p0002f20 & Ankyrin repeat and $\mathrm{KH}$ domain-containing protein & $1.00 \mathrm{E}-12$ & $2.50 \mathrm{E}-05$ & 0,57 \\
\hline & CU682447 & oygd10b10n08r1 & NA & & $1.88 \mathrm{E}-04$ & 0,58 \\
\hline & CU685072 & oypg10b07d22r1 & Putative ankyrin repeat protein & $3.00 \mathrm{E}-04$ & $2.47 \mathrm{E}-04$ & 0,59 \\
\hline & CU685188 & oypg10b07f04r1 & Fibulin-5 & $7.00 \mathrm{E}-10$ & 2.63E-04 & 0,60 \\
\hline & CU683708 & oyge $09 \mathrm{~b} 12 \mathrm{~m} 14 \mathrm{r} 1$ & Neurogenic locus notch homolog protein 2 & $3.00 \mathrm{E}-13$ & $2.42 \mathrm{E}-04$ & 0,63 \\
\hline & AM857213 & $\operatorname{cdn} 21 \mathrm{p} 0004 \mathrm{f} 05$ & Mitogen-activated protein & $2.00 \mathrm{E}-54$ & $1.01 \mathrm{E}-04$ & 0,64 \\
\hline & AM855685 & cdn20p0004m19 & NA & & $5.60 \mathrm{E}-05$ & 0,65 \\
\hline & CU681533 & oygd09b07p15r1 & NA & & $1.48 \mathrm{E}-04$ & 0,66 \\
\hline & CU684209 & oyge10b13a10r1 & Tubulin alpha- 1 chain & $9.00 \mathrm{E}-07$ & 2.43E-04 & 0,66 \\
\hline & AM854778 & cdn20p0001i06 & Putative ankyrin repeat protein & $8.00 \mathrm{E}-10$ & 4.70E-05 & 0,67 \\
\hline & CU681818 & oygd09b07112r1 & NA & & $1.86 \mathrm{E}-04$ & 0,67 \\
\hline & AM857078 & $\operatorname{cdn} 21 \mathrm{p} 0003 \mathrm{o} 22$ & Complement $\mathrm{C} 1 \mathrm{q}$ tumor necrosis factor-related protein & $7.00 \mathrm{E}-07$ & $9.80 \mathrm{E}-05$ & 0,68 \\
\hline & CU681588 & oygd09b07o14r1 & NA & & $1.51 \mathrm{E}-04$ & 0,70 \\
\hline & AM856921 & $\operatorname{cdn} 21 \mathrm{p} 0003 \mathrm{~h} 18$ & Set1/Ash2 histone methyltransferase complex subunit & $3.00 \mathrm{E}-48$ & $8.30 \mathrm{E}-05$ & 0,70 \\
\hline & BQ426809 & BQ426809 & NA & & $1.40 \mathrm{E}-04$ & 0,70 \\
\hline & CU683013 & oygd10b09g16r1 & NA & & 2.12E-04 & 0,71 \\
\hline & CU683326 & oyge09b11p23r1 & NA & & 2.19E-04 & 0,73 \\
\hline & FP090952 & oyio1 $0 \mathrm{~b} 01 \mathrm{c} 01 \mathrm{r} 1$ & NA & & 2.73E-04 & 0,74 \\
\hline & AM857298 & $\operatorname{cdn} 21 \mathrm{p} 0004 \mathrm{j} 22$ & Prostaglandin E2 receptor & $2.00 \mathrm{E}-20$ & $1.05 \mathrm{E}-04$ & 0,75 \\
\hline & CU681629 & oygd09b07m17r1 & NA & & $1.52 \mathrm{E}-04$ & 0,76 \\
\hline & AM857028 & $\operatorname{cdn} 21 \mathrm{p} 0003 \mathrm{~m} 17$ & Tripartite motif-containing protein 2 & $9.00 \mathrm{E}-18$ & $9.60 \mathrm{E}-05$ & 0,76 \\
\hline & AM855543 & $\operatorname{cdn} 20 \mathrm{p} 0004 \mathrm{~d} 22$ & Inhibitor of nuclear factor kappa-B kinase subunit & $2.00 \mathrm{E}-21$ & $5.20 \mathrm{E}-05$ & 0,78 \\
\hline & CU683323 & oyge09b11i11r1 & Chitotriosidase-1 & $4.00 \mathrm{E}-26$ & 2. 14E-04 & 0,78 \\
\hline & AM856093 & $\operatorname{cdn} 21 \mathrm{p} 0001 \mathrm{c} 15$ & Superoxide dismutase $[\mathrm{Cu}-\mathrm{Zn}]$ & $7.00 \mathrm{E}-23$ & $6.20 \mathrm{E}-05$ & 0,79 \\
\hline & AM853576 & cdn19p0002a07 & Neurogenic locus notch protein homolog & $3.00 \mathrm{E}-14$ & $2.40 \mathrm{E}-05$ & 0,80 \\
\hline & CU681673 & oygd09b07j05r1 & NA & & $1.53 \mathrm{E}-04$ & 1,13 \\
\hline & AM856775 & $\operatorname{cdn} 21 \mathrm{p} 0003 \mathrm{~b} 03$ & Prostaglandin E2 receptor & $7.00 \mathrm{E}-22$ & $7.90 \mathrm{E}-05$ & 1,18 \\
\hline & AM855291 & $\operatorname{cdn} 20 \mathrm{p} 0003 \mathrm{fo} 1$ & NA & & $5.20 \mathrm{E}-05$ & 1,22 \\
\hline & AM853924 & cdn19p0002p24 & Ras-like GTP-binding protein Rhol & $5.00 \mathrm{E}-25$ & $3.20 \mathrm{E}-05$ & 1,25 \\
\hline & AM866067 & $\operatorname{cdn} 37 \mathrm{p} 0026 \mathrm{k} 10$ & Zinc metalloproteinase & $9.00 \mathrm{E}-15$ & $1.88 \mathrm{E}-04$ & 1,27 \\
\hline & AM854726 & cdn20p0001f21 & Toll-like receptor 3 & $2.00 \mathrm{E}-09$ & $4.10 \mathrm{E}-05$ & 1,29 \\
\hline & AM856242 & cdn21p0001j01 & Fucolectin-7 & $8.00 \mathrm{E}-07$ & $6.30 \mathrm{E}-05$ & 1,33 \\
\hline & AM854377 & cdn19p0004f01 & Mitoferrin-1 & $5.00 \mathrm{E}-80$ & $3.50 \mathrm{E}-05$ & 1,38 \\
\hline & AM853235 & cdn19p0001b 12 & Complement C1q-like protein 4 & $2.00 \mathrm{E}-09$ & $2.11 \mathrm{E}-04$ & 1,39 \\
\hline & FP089924 & oyio09b02n18r1 & Soma ferritin & $2.00 \mathrm{E}-21$ & $2.73 \mathrm{E}-04$ & 1,43 \\
\hline
\end{tabular}




\begin{tabular}{|c|c|c|c|c|c|c|}
\hline Tissue & Genbank accession & Sigenae name & Swiss-Prot hit description & $E$ value & $\begin{array}{l}p \text { Value } \\
\text { ANOVA }\end{array}$ & $\begin{array}{l}\text { Fold chang } \\
\text { R/S }\end{array}$ \\
\hline & AM853394 & cdn19p0001i09 & Superoxide dismutase $[\mathbf{C u}-\mathrm{Zn}]$ & $2.00 \mathrm{E}-04$ & $1.20 \mathrm{E}-05$ & 1,51 \\
\hline & AM857760 & cdn37p0002c03 & Superoxide dismutase $[\mathrm{Cu}-\mathrm{Zn}]$ & $1,00 \mathrm{E}-50$ & $5,49 \mathrm{E}-05$ & 1,52 \\
\hline & AM856953 & cdn2 1p0003j05 & Leukocyte common antigen & $1.00 \mathrm{E}-08$ & $9.10 \mathrm{E}-05$ & 1,54 \\
\hline & CU683194 & oyge $09 \mathrm{~b} 11 \mathrm{~m} 02 \mathrm{r} 1$ & Ras-like GTP-binding protein Rhol & $6.00 \mathrm{E}-94$ & $2.13 \mathrm{E}-04$ & 1,59 \\
\hline & CU683707 & oyge $09 \mathrm{~b} 12 \mathrm{~m} 06 \mathrm{r} 1$ & Toll-like receptor 1 & $3.00 \mathrm{E}-06$ & $2.36 \mathrm{E}-04$ & 1,61 \\
\hline & AM858229 & cdn37p0003j 12 & T-complex-associated testis-expressed protein & $1.00 \mathrm{E}-50$ & $1.15 \mathrm{E}-04$ & 1,64 \\
\hline & AM854090 & cdn19p0003h 13 & C-type lectin domain family & $3.00 \mathrm{E}-05$ & $1.49 \mathrm{E}-04$ & 1,72 \\
\hline & FP091069 & oyio10b01h21r1 & Dopamine receptor 1 & $7.00 \mathrm{E}-23$ & $2.84 \mathrm{E}-04$ & 1,75 \\
\hline & CU681715 & oygd09b07k07r1 & Integrin beta-1 & $1.00 \mathrm{E}-17$ & $1.63 \mathrm{E}-04$ & 1,79 \\
\hline & CK172373 & CK172373 & NA & & $1.43 \mathrm{E}-04$ & 1,81 \\
\hline & CU681745 & oygd09b07i13r1 & B-cell lymphoma/leukemia & $1.00 \mathrm{E}-11$ & $1.72 \mathrm{E}-04$ & 1,85 \\
\hline & CU682412 & oygd10b10j02r1 & Thyroid peroxidase & $7.00 \mathrm{E}-27$ & $2.24 \mathrm{E}-04$ & 1,87 \\
\hline \multirow[t]{32}{*}{ Muscle } & FP091019 & oyio $10 \mathrm{~b} 01 \mathrm{fl} 0$ & NA & & $1,10 \mathrm{E}-04$ & 0,21 \\
\hline & AM853269 & cdn19p0001c24 & NA & & $5,10 \mathrm{E}-05$ & 0,25 \\
\hline & AM858613 & $\operatorname{cdn} 37 \mathrm{p} 0004112$ & NA & & $1,74 \mathrm{E}-04$ & 0,28 \\
\hline & AM856743 & cdn21p0002p 18 & NF-kappa-B in hibitor cactus & $6,00 \mathrm{E}-07$ & $1,79 \mathrm{E}-04$ & 0,30 \\
\hline & AM853504 & cdn19p0001n04 & NF-kappa-B inhibitor cactus & $4,00 \mathrm{E}-33$ & $4,90 \mathrm{E}-05$ & 0,30 \\
\hline & CU 686145 & oypm10b03f1 6 & Suppressor of cytokine signaling 5 & $3,00 \mathrm{E}-12$ & $6,70 \mathrm{E}-05$ & 0,34 \\
\hline & AM855031 & $\operatorname{cdn} 20 \mathrm{p} 0002 \mathrm{e} 17$ & NA & & $1,10 \mathrm{E}-04$ & 0,36 \\
\hline & CU683232 & oyge09b11m21 & Apoptosis-inducing factor 3 & $2,00 \mathrm{E}-68$ & $1,22 \mathrm{E}-04$ & 0,40 \\
\hline & CU681645 & oygd09b07p14 & Collagen alpha-2(IV) chain & $1,00 \mathrm{E}-25$ & $1,77 \mathrm{E}-04$ & 0,43 \\
\hline & AM854151 & cdn19p0003k 14 & Programmed cell death protein 10 & $6,00 \mathrm{E}-38$ & $1,91 \mathrm{E}-04$ & 0,44 \\
\hline & CU685677 & oypg10b08fl4 & Pyruvate kinase muscle isozyme & $5,00 \mathrm{E}-36$ & $1,83 \mathrm{E}-04$ & 0,48 \\
\hline & AM857924 & $\operatorname{cdn} 37 \mathrm{p} 0002 \mathrm{k} 10$ & Glucokinase & $2,00 \mathrm{E}-60$ & $1,87 \mathrm{E}-04$ & 0,49 \\
\hline & AM854961 & $\operatorname{cdn} 20 \mathrm{p} 0002 \mathrm{a} 23$ & NA & & $8,40 \mathrm{E}-05$ & 0,53 \\
\hline & CU686063 & oypm10b03a15 & Paramyosin & $2,00 \mathrm{E}-14$ & $2,03 \mathrm{E}-04$ & 0,58 \\
\hline & AM859122 & $\operatorname{cdn} 37 \mathrm{p} 0006 \mathrm{c} 18$ & Programmed cell death protein 6 & $6,00 \mathrm{E}-71$ & $1,34 \mathrm{E}-04$ & 0,70 \\
\hline & CU681507 & oygd09b07n23 & Dihydropyrimidine dehydrogenase [NADP +$]$ & $9,00 \mathrm{E}-36$ & $1,47 \mathrm{E}-04$ & 0,79 \\
\hline & AM853394 & cdn19p0001i09 & Superoxide dismutase $[\mathrm{Cu}-\mathrm{Zn}]$ & $2,00 \mathrm{E}-04$ & $4,40 \mathrm{E}-05$ & 1,10 \\
\hline & AM866876 & $\operatorname{cdn} 37 \mathrm{p} 0029 \mathrm{~d} 10$ & Phosphatidylinositol-4,5-bisphosphate 3- & $5,00 \mathrm{E}-68$ & $7,60 \mathrm{E}-05$ & 1,32 \\
\hline & AM856775 & cdn21p0003b03 & Prostaglandin E2 receptor & $7,00 \mathrm{E}-22$ & $1,11 \mathrm{E}-04$ & 1,32 \\
\hline & AM853235 & cdn19p0001b 12 & Complement Clq-like protein 4 & $2,00 \mathrm{E}-09$ & $1,98 \mathrm{E}-04$ & 1,34 \\
\hline & AM867953 & $\operatorname{cdn} 37 \mathrm{p} 0032 \mathrm{f} 24$ & Heat shock $70 \mathrm{kDa}$ protein & $3,00 \mathrm{E}-89$ & $1,16 \mathrm{E}-04$ & 1,39 \\
\hline & AM853618 & cdn19p0002c05 & Catalase & $1,00 \mathrm{E}-101$ & $1,61 \mathrm{E}-04$ & 1,41 \\
\hline & CU682412 & oygd10b10j02 & Thyroid peroxidase & $7,00 \mathrm{E}-27$ & $1,52 \mathrm{E}-04$ & 1,45 \\
\hline & AM860311 & cdn37p0009m15 & Sperm-associated antigen 6 & $2,00 \mathrm{E}-99$ & $2,80 \mathrm{E}-05$ & 1,48 \\
\hline & AM857078 & cdn21p0003o22 & Complement $\mathrm{C} 1 \mathrm{q}$ tumor necrosis factor-related protein & $7,00 \mathrm{E}-07$ & $1,65 \mathrm{E}-04$ & 1,49 \\
\hline & AM858229 & cdn37p0003j 12 & T-complex-associated testis-expressed protein & $1,00 \mathrm{E}-50$ & $1,28 \mathrm{E}-04$ & 1,56 \\
\hline & CU685371 & oypg09b06j05 & Metallothionein & $1,00 \mathrm{E}-06$ & $1,44 \mathrm{E}-04$ & 1,63 \\
\hline & AM854726 & $\operatorname{cdn} 20 p 0001 f 21$ & Toll-like receptor 3 & $2,00 \mathrm{E}-09$ & $2,70 \mathrm{E}-05$ & 1,72 \\
\hline & AJ582629 & AJ582629 & Defensin & $9,00 \mathrm{E}-07$ & $2,09 \mathrm{E}-04$ & 1,74 \\
\hline & AM856765 & $\operatorname{cdn} 21 \mathrm{p} 0003 \mathrm{a} 17$ & Bone morphogenetic protein 15 & $4,00 \mathrm{E}-06$ & $5,50 \mathrm{E}-05$ & 1,77 \\
\hline & AM857760 & cdn37p0002c03 & Superoxide dismutase $[\mathrm{Cu}-\mathrm{Zn}]$ & $1,00 \mathrm{E}-50$ & $5,49 \mathrm{E}-05$ & 1,82 \\
\hline & CU681745 & oygd09b07i13 & B-cell lymphoma/leukemia & $1,00 \mathrm{E}-11$ & $8,50 \mathrm{E}-05$ & 1,84 \\
\hline \multirow[t]{4}{*}{ Gills } & AM858409 & $\operatorname{cdn} 37 \mathrm{p} 0004 \mathrm{c} 02$ & NA & & $5,61 \mathrm{E}-05$ & 0,19 \\
\hline & AM865171 & $\mathrm{cdn} 37 \mathrm{p} 0024 \mathrm{a} 03$ & Glycogen debranching enzyme & $1,00 \mathrm{E}-104$ & $6,50 \mathrm{E}-05$ & 0,22 \\
\hline & AM866254 & $\operatorname{cdn} 37 \mathrm{p} 0027 \mathrm{c} 21$ & NFKB inhibitor interacting Ras-like 1 & $6,00 \mathrm{E}-41$ & $6,69 \mathrm{E}-05$ & 0,27 \\
\hline & AM856242 & $\operatorname{cdn} 21 \mathrm{p} 0001 \mathrm{j} 01$ & Fucolectin-7 & $8,00 \mathrm{E}-07$ & $4,83 \mathrm{E}-05$ & 0,30 \\
\hline
\end{tabular}




\begin{tabular}{|c|c|c|c|c|c|c|}
\hline Tissue & Genbank accession & Sigenae name & Swiss-Prot hit description & $E$ value & $\begin{array}{l}p \text { Value } \\
\text { ANOVA }\end{array}$ & $\begin{array}{l}\text { Fold ch } \\
\text { R/S }\end{array}$ \\
\hline & AM856743 & $\operatorname{cdn} 21 \mathrm{p} 0002 \mathrm{p} 18$ & NF-kappa-B inhibitor cactus & $6,00 \mathrm{E}-07$ & $5,21 \mathrm{E}-05$ & 0,35 \\
\hline & AM858487 & $\operatorname{cdn} 37 \mathrm{p} 0004 \mathrm{f} 18$ & Cell division control protein 42 & $4,00 \mathrm{E}-47$ & $5,64 \mathrm{E}-05$ & 0,39 \\
\hline & CU686145 & oypm10b03f1 6 & Suppressor of cytokine signaling & $3,00 \mathrm{E}-12$ & $2,82 \mathrm{E}-04$ & 0,44 \\
\hline & AM861125 & $\operatorname{cdn} 37 \mathrm{p} 0012 \mathrm{e} 07$ & Peroxisomal leader peptide-processing protease & $4,00 \mathrm{E}-07$ & $5,86 \mathrm{E}-05$ & 0,48 \\
\hline & AM862314 & $\operatorname{cdn} 37 \mathrm{p} 0015 \mathrm{j} 15$ & Pancreatic lipase-related protein & $6,00 \mathrm{E}-25$ & $6,14 \mathrm{E}-05$ & 0,48 \\
\hline & BQ426737 & BQ426737 & Integrin beta-1 & $2,00 \mathrm{E}-04$ & $1,46 \mathrm{E}-04$ & 0,50 \\
\hline & CU685188 & oypg10b07f04 & Fibulin-5 & $7,00 \mathrm{E}-10$ & $2,79 \mathrm{E}-04$ & 0,51 \\
\hline & AM858676 & $\operatorname{cdn} 37 \mathrm{p} 0004 \mathrm{o} 08$ & NA & & $5,78 \mathrm{E}-05$ & 0,51 \\
\hline & AM855451 & cdn20p0003o08 & Ubiquitin carboxyl-terminal hydrolase & $5,00 \mathrm{E}-80$ & $4,16 \mathrm{E}-05$ & 0,52 \\
\hline & AM853504 & cdn19p0001n04 & NF-kappa-B inhibitor cactus & $4,00 \mathrm{E}-33$ & $3,37 \mathrm{E}-05$ & 0,52 \\
\hline & FP091048 & oyio10b01g19 & NA & & $2,95 \mathrm{E}-04$ & 0,56 \\
\hline & CU684835 & oypg09b05h15 & Soma ferritin & $5,00 \mathrm{E}-29$ & $2,74 \mathrm{E}-04$ & 0,57 \\
\hline & CU682043 & oygd09b08f 20 & Tissue inhibitor of metalloproteases & $2,00 \mathrm{E}-04$ & $2,25 \mathrm{E}-04$ & 0,59 \\
\hline & CU682416 & oygd1 $0 \mathrm{~b} 10 \mathrm{~h} 10$ & NA & & $2,35 \mathrm{E}-04$ & 0,59 \\
\hline & AM853924 & cdn19p0002p24 & Ras-like GTP-binding protein Rhol & $5,00 \mathrm{E}-25$ & $3,58 \mathrm{E}-05$ & 0,59 \\
\hline & CU682923 & oygd10b09j18 & NA & & $2,40 \mathrm{E}-04$ & 0,60 \\
\hline & AM853819 & cdn19p0002104 & Cathepsin L & $1,00 \mathrm{E}-102$ & $3,40 \mathrm{E}-05$ & 0,61 \\
\hline & AM 862518 & $\operatorname{cdn} 37 \mathrm{p} 0016 \mathrm{c} 22$ & Stress response protein nhaX & $3,00 \mathrm{E}-07$ & $6,16 \mathrm{E}-05$ & 0,61 \\
\hline & CU681765 & oygd09b07h14 & Glutathione-requiring prostaglandin D synthase & $1,00 \mathrm{E}-05$ & $2,24 \mathrm{E}-04$ & 0,61 \\
\hline & AM855176 & cdn20p0002n 15 & Cell death-related nuclease & $5,00 \mathrm{E}-24$ & $3,82 \mathrm{E}-05$ & 0,61 \\
\hline & CU681565 & oygd09b07a19 & Soma ferritin & $1,00 \mathrm{E}-25$ & $1,71 \mathrm{E}-04$ & 0,62 \\
\hline & AM857924 & $\operatorname{cdn} 37 \mathrm{p} 0002 \mathrm{k} 10$ & Glucokinase & $2,00 \mathrm{E}-60$ & $5,57 \mathrm{E}-05$ & 0,66 \\
\hline & AM856068 & $\operatorname{cdn} 21 \mathrm{p} 0001 \mathrm{~b} 14$ & Testicular haploid expressed gene protein & $7,00 \mathrm{E}-11$ & $4,40 \mathrm{E}-05$ & 0,67 \\
\hline & AM854685 & cdn20p0001e04 & Inositol hexakisphosphate kinase & $4,00 \mathrm{E}-22$ & $3,71 \mathrm{E}-05$ & 0,68 \\
\hline & AM854877 & $\mathrm{cdn} 20 \mathrm{p} 0001 \mathrm{~m} 18$ & Phospholipid hydroperoxide glutathione peroxidase & $3,00 \mathrm{E}-51$ & $3,80 \mathrm{E}-05$ & 0,68 \\
\hline & CU683232 & oyge09b11m21 & Apoptosis-inducing factor 3 & $2,00 \mathrm{E}-68$ & $2,41 \mathrm{E}-04$ & 0,80 \\
\hline & AM855818 & $\operatorname{cdn} 20 \mathrm{p} 0005 \mathrm{~d} 23$ & Glutathione peroxidase 3 & $1,00 \mathrm{E}-35$ & $4,20 \mathrm{E}-05$ & 0,82 \\
\hline & CU681645 & oygd09b07p14 & Collagen alpha-2(IV) chain & $1,00 \mathrm{E}-25$ & $1,82 \mathrm{E}-04$ & 0,84 \\
\hline & CU684230 & oyge 10b $13 \mathrm{~d} 08$ & Big defensin & $3,00 \mathrm{E}-20$ & $2,49 \mathrm{E}-04$ & 0,86 \\
\hline & AM857294 & $\operatorname{cdn} 21 \mathrm{p} 0004 \mathrm{j} 16$ & Carnitine O-palmitoyltransferase & $2,00 \mathrm{E}-17$ & $5,29 \mathrm{E}-05$ & 0,87 \\
\hline & AM863247 & cdn37p0018f04 & Chorion peroxidase & $3,00 \mathrm{E}-22$ & $6,30 \mathrm{E}-05$ & 0,87 \\
\hline & CU682536 & oygd1 0 b $10 \circ 09$ & NA & & $2,39 \mathrm{E}-04$ & 0,88 \\
\hline & AM867148 & cdn37p0030b11 & NA & & $1,07 \mathrm{E}-04$ & 0,88 \\
\hline & AM857637 & $\operatorname{cdn} 37 \mathrm{p} 0001115$ & Peroxiredoxin-5, mitochondrial & $1,00 \mathrm{E}-29$ & $5,47 \mathrm{E}-05$ & 0,89 \\
\hline & AM857760 & cdn37p0002c03 & Superoxide dismutase $[\mathrm{Cu}-\mathrm{Zn}]$ & $1,00 \mathrm{E}-50$ & $5,49 \mathrm{E}-05$ & 1,14 \\
\hline & AM854726 & $\operatorname{cdn} 20 \mathrm{p} 0001 \mathrm{f} 21$ & Toll-like receptor 3 & $2,00 \mathrm{E}-09$ & $3,72 \mathrm{E}-05$ & 1,14 \\
\hline & AM853394 & cdn19p0001i09 & Superoxide dismutase $[\mathrm{Cu}-\mathrm{Zn}]$ & $2,00 \mathrm{E}-04$ & $3,37 \mathrm{E}-05$ & 1,16 \\
\hline & CU682412 & oygd10b10j02 & Thyroid peroxidase & $7,00 \mathrm{E}-27$ & $2,32 \mathrm{E}-04$ & 1,21 \\
\hline & AM869445 & cdn37p0036k04 & Testis-specific serine/threonine-protein kinase & $4,00 \mathrm{E}-13$ & $1,45 \mathrm{E}-04$ & 1,23 \\
\hline & AM856093 & $\mathrm{cdn} 21 \mathrm{p} 0001 \mathrm{c} 15$ & Superoxide dismutase $[\mathrm{Cu}-\mathrm{Zn}]$ & $7,00 \mathrm{E}-23$ & $4,70 \mathrm{E}-05$ & 1,25 \\
\hline & AM858229 & cdn37p0003j 12 & T-complex-associated testis-expressed protein & $1,00 \mathrm{E}-50$ & $5,61 \mathrm{E}-05$ & 1,27 \\
\hline & CU685371 & oypg09b06j05 & Metal lothionein & $1,00 \mathrm{E}-06$ & 2,81E-04 & 1,28 \\
\hline & AM856775 & cdn21p0003b03 & Prostaglandin E2 receptor & $7,00 \mathrm{E}-22$ & $5,26 \mathrm{E}-05$ & 1,28 \\
\hline & AM856052 & $\operatorname{cdn} 21 \mathrm{p} 0001 \mathrm{a} 22$ & Heat shock protein $105 \mathrm{kDa}$ & $2,00 \mathrm{E}-27$ & $4,40 \mathrm{E}-05$ & 1,32 \\
\hline & AM855723 & cdn20p0004p01 & Gametogenetin-binding protein & $2,00 \mathrm{E}-66$ & $4,17 \mathrm{E}-05$ & 1,32 \\
\hline & AM855417 & $\operatorname{cdn} 20 \mathrm{p} 0003 \mathrm{~m} 12$ & Peroxisomal carnitine $\mathrm{O}$-octanoyltransferase & $1,00 \mathrm{E}-64$ & $3,87 \mathrm{E}-05$ & 1,34 \\
\hline & FP089924 & oyio09b02n18 & Soma ferritin & $2,00 \mathrm{E}-21$ & 2,91E-04 & 1,36 \\
\hline & CU681715 & oygd09b07k07 & Integrin beta-1 & $1,00 \mathrm{E}-17$ & $2,00 \mathrm{E}-04$ & 1,40 \\
\hline
\end{tabular}




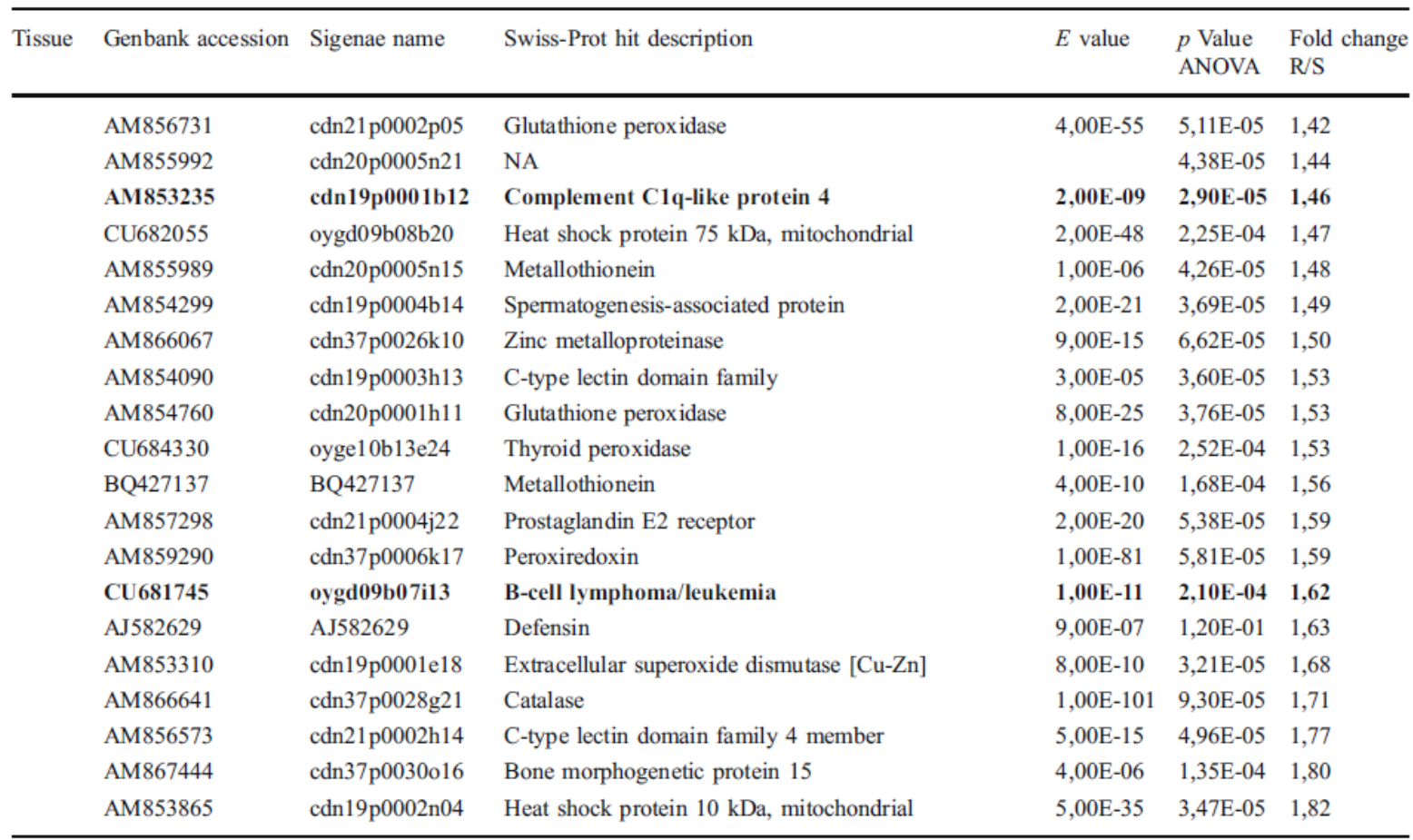




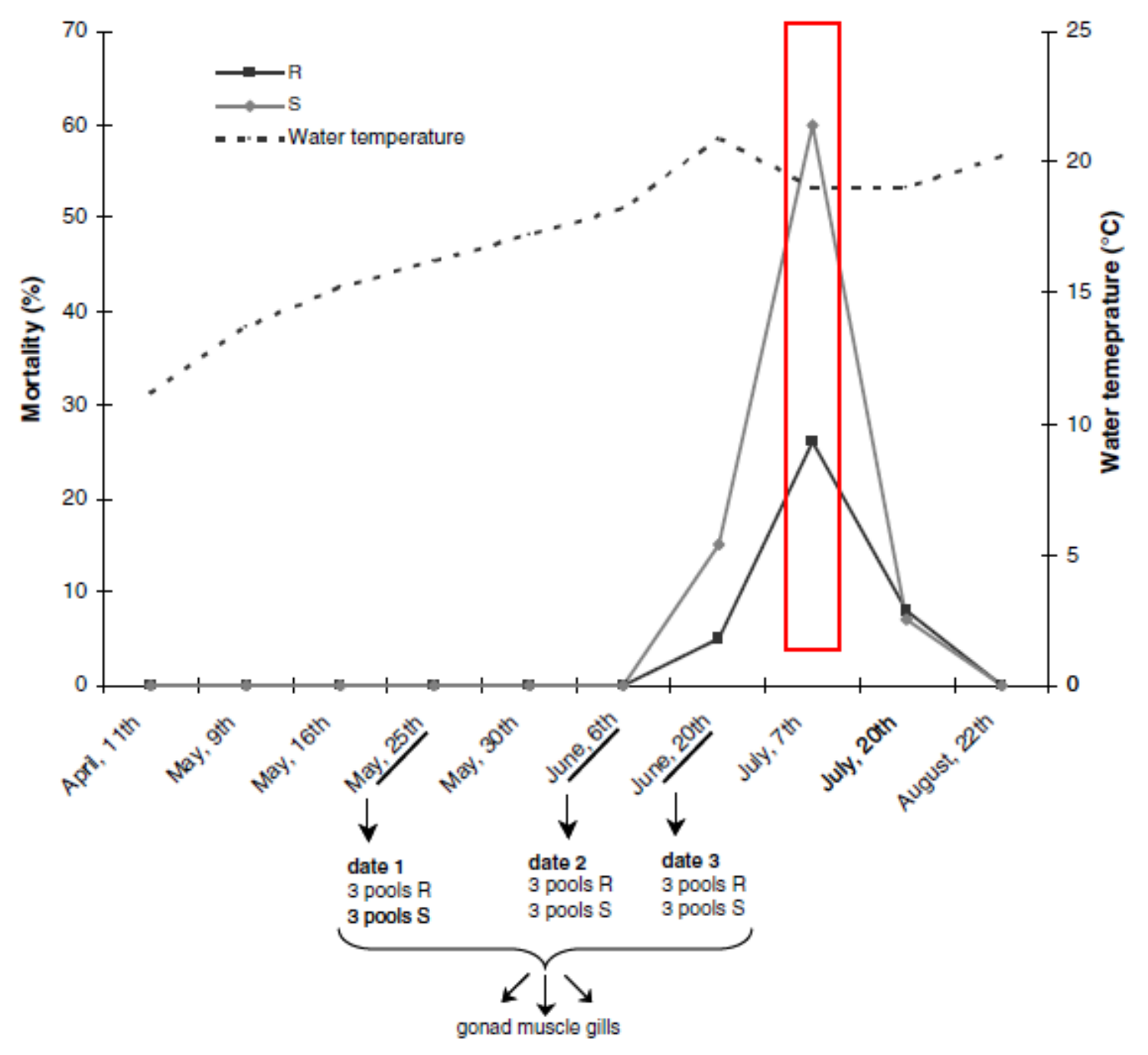

Figure 1: Mortality rates of Resistant (black) and Sensitive (gray) oysters lines during a field experiment (Fort Espagnol, Britanny, France 2005). The sampling dates were used to assess the mortality rates of the studied oysters. The three sampling dates used for microarray analyses are underlined; date 1: May, $25^{\text {th }}$, date 2 : June, $6^{\text {th }}$, and date 3 : June, $20^{\text {th }}$. For each date, three tissues were sampled in 3 pools containing 8 oysters: gonad, muscle and gills. The box indicates the mortality peak. 

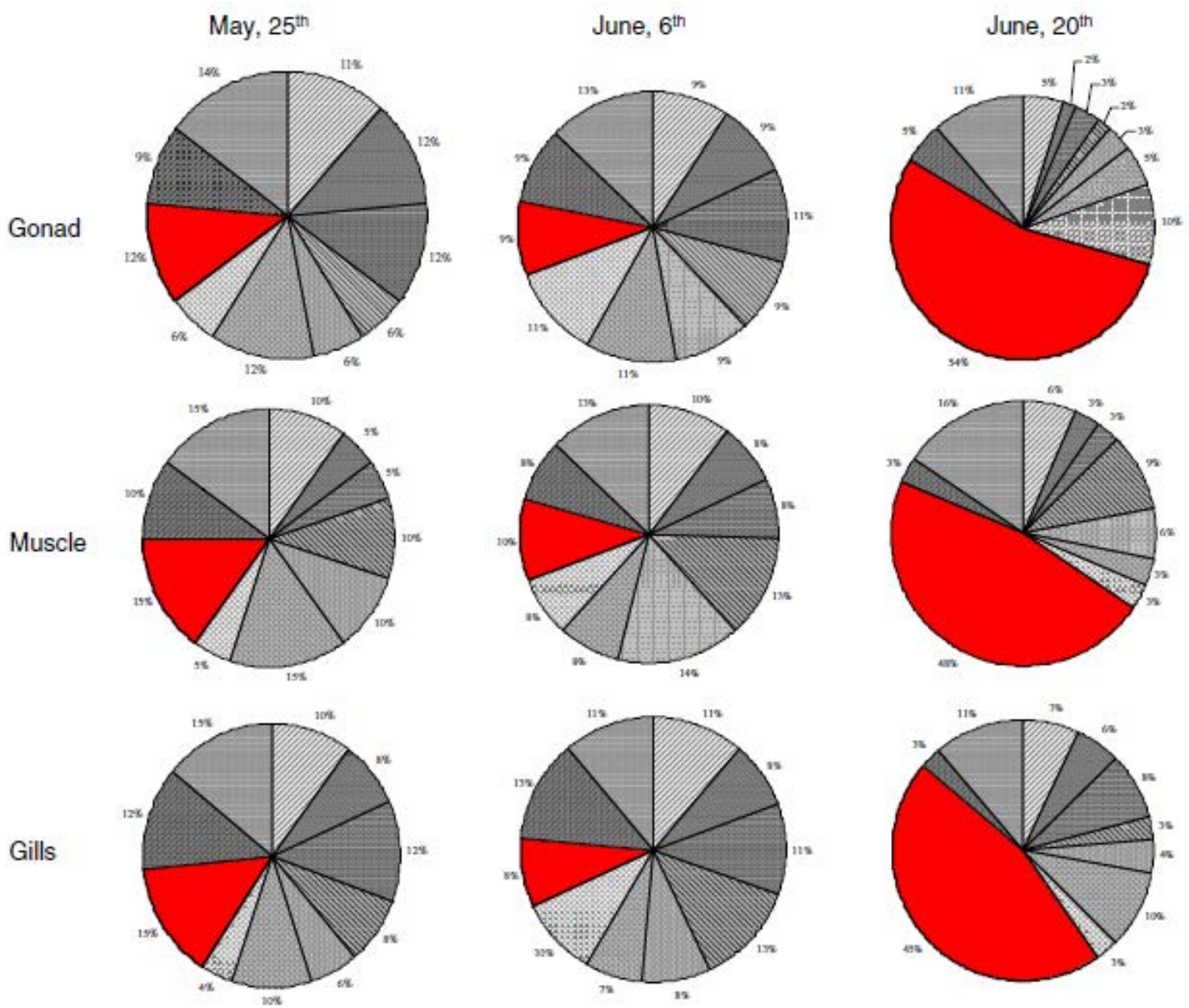

\footnotetext{
QReproduction

口Lipid metabolic process

QResponse to stress

aCell death

口Catabolic process

$\square$ Antioxidant activity

口Growth

Dimmune response

GEnergy reserve metabolic process

口NA
}

Figure 2: Gene ontology analysis of the differentially expressed genes between resistant and susceptible oyster lines for three sampling dates and three tissues (muscle, gills and gonad). The three dates, May $25^{\text {th }}$, June $6^{\text {th }}$ and June $20^{\text {th }}$, are in columns. Each part of the graph represents the percentage of a specific biological process among the selected genes. More specifically, the percentage of genes associated with "immune response" biological process for each date and each sample are shown in red. 
Gonad

Gills

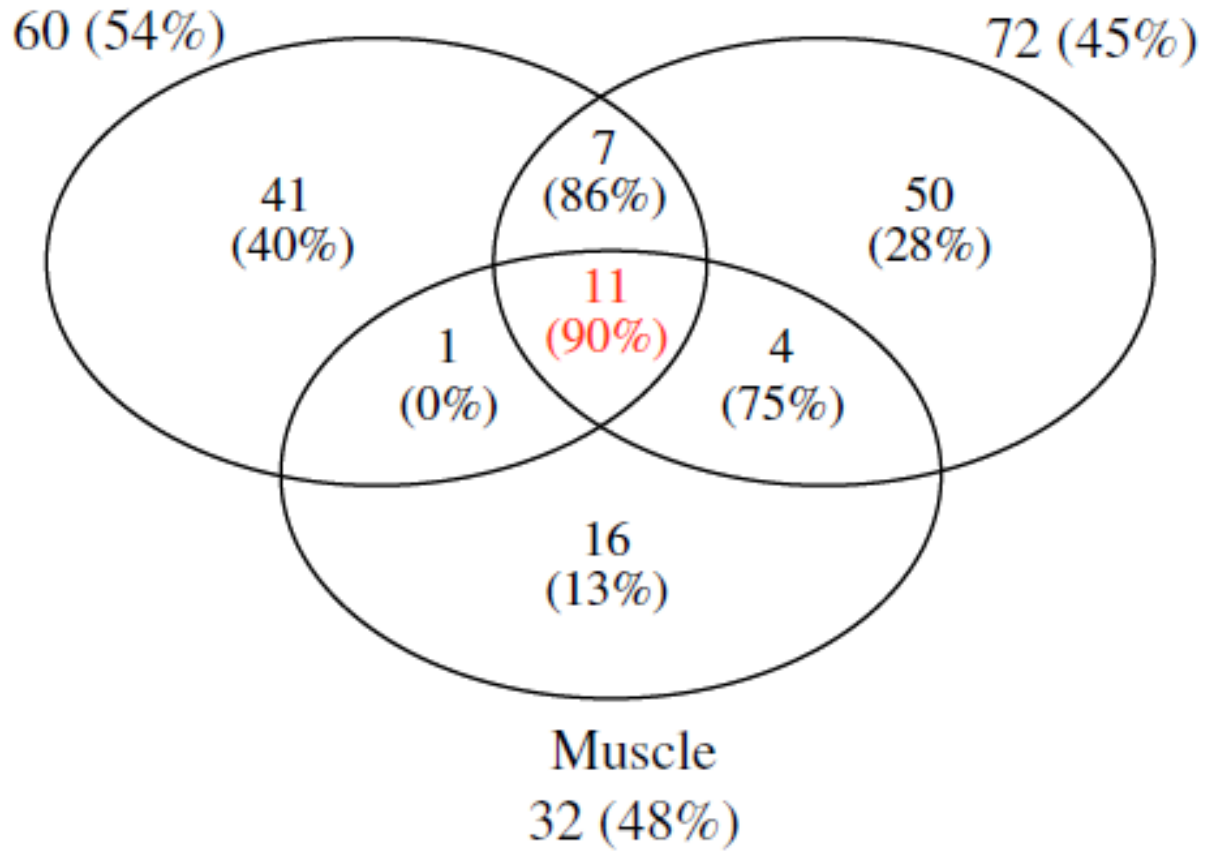

Fig. 3 Venn diagram representing the common selected ESTs between resistant and susceptible oyster lines sampled at the date June 20th for three tissues (muscle, gills, and gonad). The number of selected ESTs is given followed into brackets by the percentage of ESTs linked to "immune response" gene ontology category 

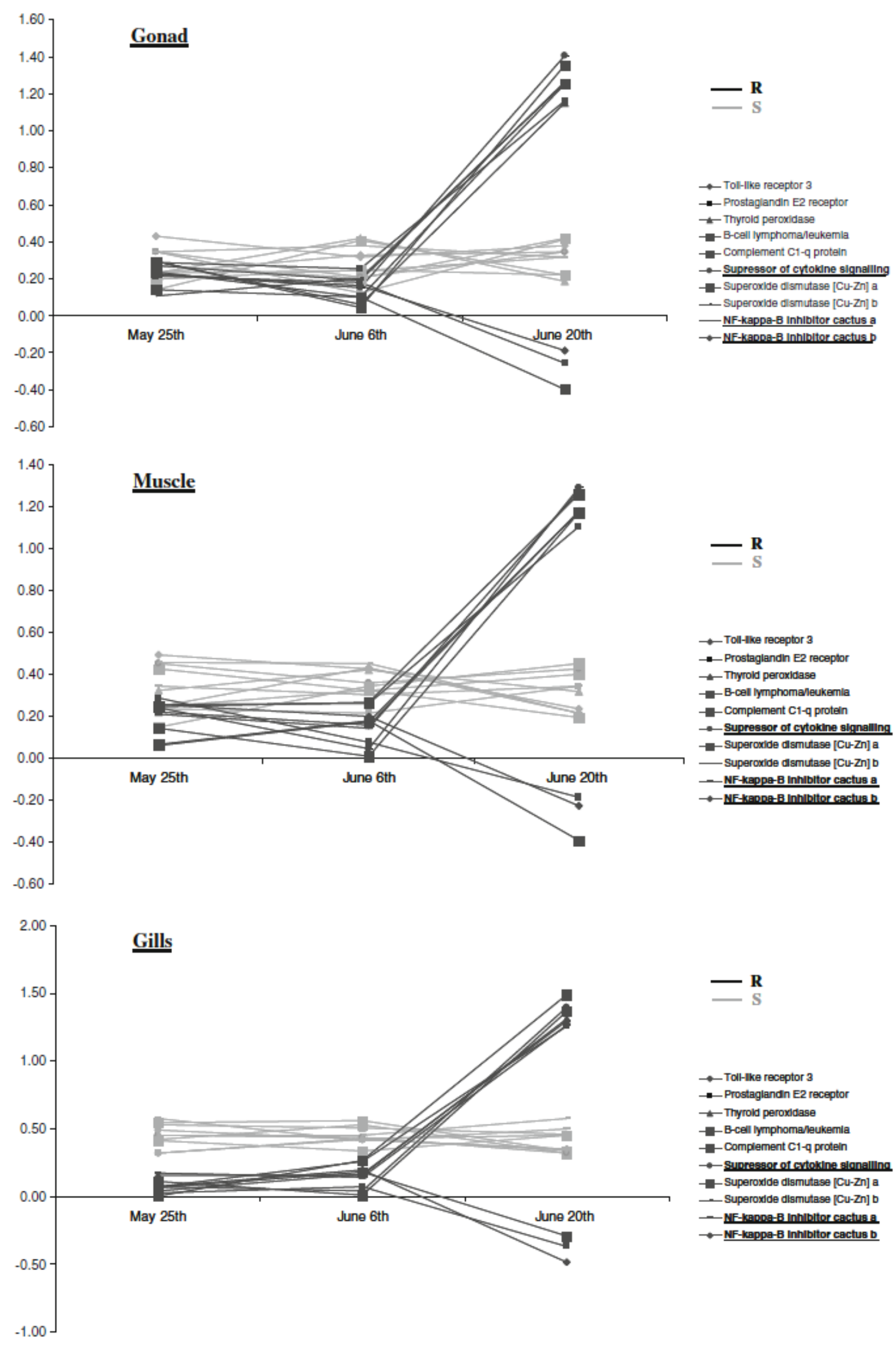

Figure 4: Time-course patterns for the 10 immune-relevant ESTs selected as differentially expressed between resistant and susceptible oyster lines inferred from the microarray data. $X$ axis represents the three dates of sampling (May 25 $5^{\text {th }}$, June 6th and June 20th) for susceptible (S, grey) and resistant (R, black) oysters. $\mathrm{Y}$ axis represents the transformed normalized Cy5 log value obtained for $\mathrm{R}$ and $\mathrm{S}$ samples for each dates. Genes which are significantly under-expressed in R compared with $S$ samples at June 20th are underlined. The results of each tissue, gonad, muscle and gills are presented separately. 